\title{
Analysing the Role of Culture in IS Studies
}

\author{
Hayel T. Ababneh ${ }^{1} \&$ Fayiz D. Shrafat ${ }^{2}$ \\ ${ }^{1}$ Department of Business Administration, Al Al-Bayt University, Jordan \\ 2 Department of Management, The Hashemite University, Jordan \\ Correspondence: Hayel T. Ababneh, Department of Business Administration, Al Al-Bayt University, Jordan. \\ E-mail: hayelababneh@aabu.edu.jo
}

Received: August 17, 2014

Accepted: September 15, 2014

Online Published: October 25, 2014

doi:10.5539/ibr.v7n11p165

URL: http://dx.doi.org/10.5539/ibr.v7n11p165

\begin{abstract}
The purpose of the present paper is to theoretically review the role of culture on using Information Systems. This study revises, criticises, and extends cultural dimensions developed by main scholars such as Hofstede and Hall. Furthermore, it discusses the two levels of national and organisational culture and their role in shaping the use of Information Systems and its development. It significantly explains various levels of use of IS among different nations and industries located in different cultures. The results demonstrate the important role of national and derived organizational culture as immediate antecedents to and key success factor of using Information Systems. Because this revision outlines major lines of research in the field, it can be useful for both academics and practitioners. Further, it discusses limitations of existing research and suggests a new dimension of culture (Traditionalism-Modernity) which stimulates further research to investigate its validity in characterising diverse nations in terms of their national culture.
\end{abstract}

Keywords: information systems, IT values, national culture, organizational culture

\section{Introduction}

Early researchers assumed that technology has deterministic and objective impacts on organisations. Such research deals with technology as an independent variable affecting the behaviour of people or organisations (Giddens, 1984) and ignore human actions in designing, developing, appropriating and changing technology. Later researchers see technology as a dependent variable, as the product of the interactions and political choices of human actors.

Subsequently, various approaches which link technology and sociology have gained momentum since the early 1980s. They acknowledge the plurality of concerns and emphasise the human element in the shaping of social conditions (Ciborra, 2000). It became obvious that such theoretical perspectives contribute to a new understanding of the socio-technical relationship. Although these approaches show that technology is shaped by various organisational and non-organisational factors including cultural and societal systems, these approaches have only a limited contribution to revealing how cultural factors can influence the development of technology (Klein \& Kleinman, 2002). Thus, this paper focuses on the contextual settings necessary to understand the cultural role shaping technology and specifically IS.

We believe that such a discussion is important for two reasons: First; understanding the role of culture at various levels, including national and organisational is important to the study of the successful implementation and use of information systems (Leidner \& Kayworth, 2006). Second; IS and culture are two closely related issues in any firm because people are a common factor, that's why understanding the cultural consequences of organisational behaviour linked to IS implementation is very crucial to assure success, otherwise such implementations are very likely to fail in spite of the amount of money invested in these systems (Claver et al., 2001).

\section{The Influence of National Culture}

From the point of view of anthropologists culture is "the way of life of a community" (Barbu, 1971, p. 3). Broadly culture refers to a set of beliefs, values, attitudes and behaviours normally shared by a society (Cooper, 1994) which distinguishes a single member or a group of people from another. Although there is no agreement between scholars on a particular definition of this concept numerous scholars have discussed the influence of culture shared by a group of people on values and behaviour (Rhinesmith, 1970) in a variety of ways that can 
speed up or delay the implementation of IT/IS. Based on Hofstede $(1983,1980)$ national culture is grouped into five basic dimensions: Power Distance, Individualism-Collectivism, Uncertainty Avoidance, Masculinity-Femininity, and Long Term-Short Term Orientation.

\subsection{Power Distance}

Refers to the degree to which the less powerful members of organisations within a country expect and accept that power is distributed unfairly (Hofstede, 1980). In the culture of low power distance the relationship between superior and subordinate is interdependent. Low power distance cultures exhibit relatively few layers (decentralisation). On the other hand in a culture of high power distance there is centralisation, respect for the hierarchy in an organisation and autocratic leadership.

Regarding the cultural effect on IS; power distance can affect the design of websites. High power distance organisations can design their websites in a way that emphasise the symbols of their power, whereas in low power distance organisations they focus on customers or the services provided (Marcus \& Gould, 2000). High power distance organisations may use Information and Communication Technology (ICT) as a communication tool, in contrast, low power distance organisations favour face to face communication (Ali et al., 2002).

\subsection{Individualism-Collectivism}

This scale is a measure of whether people prefer to work individually or in cohesive groups (Hofstede, 1991). A collectivistic culture is characterised by close ties between individuals, often extended families (with uncles, aunts and grandparents), and sharing of responsibility. People in collectivistic cultures learn to think in terms of "we". In an individualistic culture everyone seeks self-actualisation; individuals tend to form looser relationships and learn to think in terms of "I". The differences between individualism and collectivism are illustrated in the table shown below.

Table 1. Differences between individualism and collectivism

\begin{tabular}{|c|c|}
\hline Individualism & Collectivism \\
\hline $\begin{array}{l}\text { Everyone grows up to look after him/herself and his/herself } \\
\text { immediate family only. }\end{array}$ & $\begin{array}{l}\text { People are born into extended families or others in groups } \\
\text { which continue to protect them in exchange for loyalty }\end{array}$ \\
\hline Identity is based on the individual & Identity is based on the social network to which one belongs \\
\hline Low-context communication & High-context communication \\
\hline $\begin{array}{l}\text { Employee-employer relationship is a contract supposed to be } \\
\text { based on mutual advantage }\end{array}$ & $\begin{array}{l}\text { Employee-employer relationship is received in moral terms, } \\
\text { like a family link }\end{array}$ \\
\hline Management is management of individuals & Management is management of groups \\
\hline
\end{tabular}

Source: (Hofstede, 1980, cited in Kang and Araujo 2006).

IS can be used to encourage collectivism by adopting intranet, online discussions and Group Support Systems (GSS) to facilitate participative decision making via group discussions. However, Ho et al. (1989) argue that low individualism cultures may not prefer a computer-based communications because it lessens the group effect. In collectivist cultures that use computer-based communications you cannot pick up signals about the social situation and therefore there would be a tendency toward face-to-face contact across all communications tasks (Straub et al., 1997).

The study of consumer attitudes toward the Internet by Chau, Cole et al. (2002) demonstrated how attitudes vary significantly between Hong Kong (tendency to collectivism with shared loyalty and relationships) and the United States (tendency to individualism represented by personal competence and self-loyalty). Consequently the use of Internet varied noticeably between Hong Kong where the Internet is mainly used for social communication while in USA it is used mainly to search for information. In their study of the effect of culture on Group Decision Support Systems (GDSS), specifically Decision Conferencing (DC), Quaddus and Tung, (2002) reveal that culture plays a significant role in the effectiveness of decision making and the type of technologies used in Decision Conferencing. The use of Decision Conferencing differs according to people's values, preferences and beliefs. They conclude that it is important to consider the issue of cultural differences that explain possible differences in the use of IS.

\subsection{Uncertainty Avoidance}


Refers to the stability and level of ambiguity accepted in an organisation. People with high uncertainty avoidance try to limit conflict and risk while people with low uncertainty avoidance encourage conflict and risk taking (Swierczek, 1994). Uncertainty avoidance relates to a society's tolerance for uncertain, ambiguous, unstructured, unknown, surprising and different situations; it is about searching for truth. To minimise these situations high uncertainty avoidance cultures impose strict laws and regulations, safety and security measures.

For uncertain and ambiguous tasks it is thought that people will use face-to-face communication. For certain and clear tasks they use electronic media such as e-mail that are understood to be rather simple channels (Daft et al., 1986). In contrast, Steensma et al. (2000) found that firms with high uncertainty avoidance are more likely to use IT to avoid uncertainty. Firms are more willing to be exposed to the risks of uncertainty without the structure of IT. Additionally Leidner et al. (1999) argued that cultural values influence perceptions of the outcomes of executive information systems (EIS) use. They concluded that in countries with lower power distance and uncertainty avoidance technology was more favourably perceived.

\subsection{Masculinity-Femininity}

This dimension compares between the rational achievement orientation and the emotional affiliation orientation. It represents the degree to which dominant values in societies are masculine (authoritative, assertive, competitive and acquisitive) rather than feminine (caring, people focused, concerned with life and environment quality). Masculine traits include assertiveness, materialism/material success, self concern, strength, power and individual achievements. A high masculine culture is highly related to interpersonal presence, so using technologies such as e-mail would not be favoured. In strong feminine cultures, face-to-face communications with rich interactional cues are necessary (Hill et al., 1998).

\subsection{Long Term-Short Term Orientation}

Based on Confucian dynamism, Hofstede collaborated with Chinese scholars and added the fifth dimensions which contrasts long and short term orientation. In this dimension planning and decision making are important to a long term orientation (Inman et al., 2010). Thus organisations with a long term orientation may be more enthusiastic about using technology to assist in long term planning and decision making. It may be preferred to extend technology, regardless of the setting up costs, for the benefit of achieving long term objectives. Rose et al., (2003) investigated time-orientation as a cultural value. They concluded that subjects from monochronic cultures (United States and Finland) tended to be more concerned with website delays than those from polychronic cultures (Egypt \& Peru).

As another way of analysing cultural differences between nations, Hall, (1976) has suggested the two extremes of context cultures which are high context and low context cultures.

\subsection{High Context-Low Context}

Classifying culture into high and low-context is useful in explaining how people are socially bonded, responsible, committed, socially harmonised and communicated. Therefore it helps people to understand cultural differences more easily (Kim et al., 1998). A high-context culture is one in which people have intimate relationships with each other, a structure of social hierarchy exists and information is widely shared through simple messages with deep meaning (Kim et al., 1998). There is an emphasis on conformity and group orientation so the bonds between people extend beyond one's family to friends and society. Thus people are very committed to their actions and utterances. In terms of responsibility people in authority are personally responsible for the actions of subordinates, right down to the bottom of the hierarchy. For the purpose of saving face and in order to avoid social disharmony, high contextualised people tend to keep away from direct confrontation. Communication in a high context culture is fast, economical, efficient and satisfying. On the other hand in a low-context culture bonds between people are fragile. Thus people are highly individualised, alienated and fragmented. In terms of responsibility; it is diffused throughout the system (Hall, 1976).

Although these dimensions suggested by Hall, (1976) and Hofstede, (1983) have a widespread reputation, they are not sufficient to explain how culture can affect individual and group behaviour, and thus implementation and use of information technology within a society or organisation. Some cultural variations are overlooked such as religion and ethnocentrism. However Hofstede's work on culture gives a preliminary understanding to initiate a discussion of the impact of organisational culture. Although it is very widely cited it does not escape criticism. IritAlony, (2007) criticised the work of Hofstede by highlighting many of its shortcomings. In addition to its outdated results it focused on collecting the perceptions of employees working in a single company. It is also criticised for its inability to give sufficient information about cultural differences. Thus it is strongly recommended that other dimensions are added to the existing few dimensions (Hofstede, 2002). 
In analysing these cultural studies it is notable that the level of modernity in nations is disregarded. Some societies can be distinguished from others in terms of their adherence to cultural heritage and maintenance of past ways and inclination to value their heritage and appreciate their traditions and customs. On the other hand some other nations pay more attention to modernity and try to develop their current reality through discarding the past and heading for the future in all spheres of life. Other nations however could be classified as an interface of traditional and modern culture. Pun et al., (2000) state that Chinese managers follow a blend of modern management philosophies developed by the western business schools, and traditional Chinese thinking that form a base for improving commitment and participation. It could be argued that management practices are influenced by the wide array of traditional ideas, institutions and culture. Thus, we suggest to incorporate Traditionalism-Modernity to the preceding dimensions of national culture.

\subsection{Traditionalism-Modernity}

In traditionalism people feel proud of their history and accordingly they value their past experiences highly, they are more interactive and supportive of each other, harmonised and unified, sticking to their beliefs, attitudes and values, unreceptive to progressive thoughts and conservative. On the other hand modernity is characterised by the inclination towards respecting others' beliefs and attitudes and challenging the status quo, people are risk takers and optimistic about the future. The perception of the importance of traditionalism or modernity may be reflected in the style of managing business organisations. According to this way of thinking, managers might move towards innovations and improvements or towards keeping the traditional style of management and rejecting any kinds of change.

\section{The Influence of Organisational Culture}

Organisational culture (OC) is derived from national culture and defined as "all the interactions, which take place between people, their relationships, and the feeling engendered by their behaviour" (Evans et al., 1996, p. 78). Davis, (1990) asserts that OC is concerned with how to manage, and how to compete. According to Schein, (2010, p. 18) organisational culture is defined as the:

"Pattern of shared basic assumptions learned by a group as it solved problems of external adaptation and internal integration which has worked well enough to be considered valid and therefore, to be taught to new members as the correct way to perceive, think, and feel in relation to these problems".

There is little agreement on the way to categorise OC. Cameron and Quinn, (2011) classified OC by four quadrants; the "hierarchy (control) culture" defined by maintaining efficient, reliable, fast, smooth flowing production or services; the "market (compete) culture" which concentrates on competitiveness, productivity and a need for stability and control; the "clan (collaborate) culture" in which an extended family shares values, beliefs and goals, and participation; and finally the "adhocracy (create) culture" that concentrates on dynamism, entrepreneurship and creativity. Another kind of classification was developed by Wallach, (1983) where three types of OC are distinguished: bureaucratic, innovative and supportive. Schein, (2010) lists a group of dimensions to describe the organisational culture as follows: the behavioural regularities and interactions between people, group norms, espoused values, formal philosophy, implicit rules, climate, embedded skills, habits of thinking, shared meanings, root metaphors and symbols, formal rituals and celebrations (pp. 14-16). Organisations are differentiated according to these manifestations of culture whether visible or not. These values or visible behaviours are determined and formulated by some individual, organisational and industrial characteristics such as people's cultural background and the organisational structure.

The paradigm cultural web (Johnson et al., 2008) contains six elements of OC. The web illustrates the behaviour of employees with each other and towards the external environment. These elements are stories which are told by employees to each other about important events, successes, disasters and heroes; symbols include logos, office structures, dress codes, job titles and the type of language and terminology commonly used in an organisation; rituals and routines which are the special events through which employees learn what is important in the organisation; power structure which relates to the distribution of power among employees in the organisation; control systems which include the pay, measurements and reward systems; organisational structure in terms of functions, departments, geographically-based business units, product-based business units, flat management hierarchies and large bureaucratic hierarchies (Johnson et al., 2008, Ward \& Peppard, 2002). 


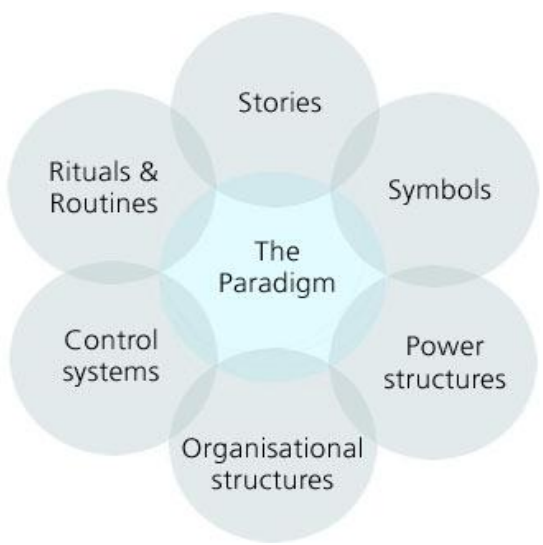

Figure 1. Paradigm cultural web

Source: (Johnson et al., 2008).

OC is a set of observable and unobservable characteristics (Capon \& Disbury, 2000). Observables include values, symbols, rituals, behavioural patterns, language, rules and stories shared by members of a specific organisation, while unobservable characteristics include the shared values, norms, beliefs and assumptions of the organisation members. Both of these explain how internal problems are regularly solved and how the organisation deals with other issues related to customers, suppliers and the environment. This blend of characteristics illustrates the way things are done in an organisation.

Ahmed, (1998) states that a strong relationship exists between the corporate culture of an organisation and administrative and operational processes. For instance entrepreneurial, flexible, and innovative organisations will employ technology more efficiently or effectively than those organisations driven by cost efficiency (Sabherwal \& Chan, 2001). Entrepreneurial firms might utilise certain technology more effectively or efficiently than other firms.

Quinn, (1988) developed a model that constituted of two axes; one for internal and external focus and the other representing the level of flexibility and control. Consequently the model has four quadrants; support orientation (internal flexibility) covering participation, trust, group cohesion, informal and verbal communication; innovation orientation (external flexibility) describing learning from outside the borders of the organisation, risk taking, creativity, informal and cross way communication; rule orientation (internal control) relates to respect for authority, specialisation and formal ways of communicating; goal orientation (external control) relates to the setting of objectives taking into considerations the external environment.

Organisational culture is regularly identified as consisting of a number of elements. One of these elements is organisational trust, which has been studied by many researchers (Fink, 1998, Brien, 1998). According to (Ruppel \& Harrington, 2001), ethical culture (an atmosphere of trust and concern for other people), developmental culture (flexibility and innovation) and hierarchical culture (policies, procedures and information management) facilitate the implementation of an intranet. They recommended management ensure that the appropriate values are in place to optimise intranet implementation and its subsequent use. Another way of categorising the features of organisational culture was proposed by Hofstede, (1998) who demonstrated six independent dimensions by which organisational culture could be described. Hofstede's six dimensions are:

Process-oriented versus Results-oriented: this dimension differentiates between the concentration on means or ends (goals) while performing tasks; if work is done in a routine and bureaucratic way it is process oriented and then culture could be described as a weak one but if the organisational units focus on achieving results with little interest in the means then the culture could be described as strong.

Job-oriented versus Employee-oriented: the former focuses on doing jobs and the performance level of employees but the latter shows a wider responsibility that it focuses on the employees well being.

Professional (highly educated employees) versus Parochial (basically knowledgeable employees): in contrast to professional culture parochial people feel that their behaviour in the home as well as on the job is influenced by the organisational norms. They have a narrow vision of the future and are characterised by high loyalty to the employing organisation (Gouldner, 1958).

Open versus Closed systems: how well or otherwise the organisation deals with external circumstances. In an 
open system people are easily familiarised while in a closed system familiarity would take long time.

Tight versus Loose internal control: this dimension measures the degree of control maintained over employees. The most valuable goal of tight control is to achieve lower costs, to keep the time from being wasted and to perform tasks effectively.

Pragmatic (Flexibility) versus Normative way (Rigidity) of dealing with the environment: in the pragmatic organisation there is a strong need to serve customers at the highest level while in normative organisations, following rules and procedures is more important than achieving results.

According to Martinsons, (1994) political and cultural factors account for more of the difference in IT use between organisations than macroeconomic or technical factors. Similarly, Robey and Rodriguez-Diaz, (1989) assert that the implementation success of accounting information systems may be a result of similar cultural values shared between the headquarters and their subsidiaries. In another study conducted by Harper and Utley, (2001) it was found that cultures with people orientation tended to have superior levels of implementation success than those cultures with more production orientation. The same study revealed a number of cultural attributes that had a positive correlation with implementing and using IT systems. These attributes are autonomy, flexibility, team-oriented work, trust and sharing information freely. In a more task-oriented culture, Kanungo, (1998) found that computer-network use had more impact on user satisfaction than in people-oriented cultures. On the other hand the cultural values that dominate military organisations contributed to less successful implementation of information systems (Tolsby, 1998). Robbins, (1990) found that a culture characterised by effectively integrated subgroups would yield improved technology performance outcomes. This suggests that integrated cultural values among organisational subgroups will lead to more efficient use of IT, especially when subgroups are interdependent. In summary, when IS and OC are in harmony then IS will be accepted and readily implemented, communication become easier, it creates cohesion among the members of a firm and the anxiety created by IS is minimised (Claver et al., 2001).

\section{Methodology}

Due to the fact that a large body of culture literature exists, we chose to limit our analysis of research studies to those where both IT and culture were significant themes of the manuscript. The analysis varied from an extraction of general themes to a specific and detailed analysis. This approach was implemented in order to eliminate the possibility of having an unmanageable amount of articles with limited value. In spite of this rich tradition of inquiry in both organizational and national-cultural IS research, we believe that a comprehensive review that examines both streams of IT-culture research can help provide a more complete perspective of the relationship of culture to IT (Leidner \& Kayworth, 2006).

\section{Conclusion}

This paper analyse the literature addressed cultural influence on organisational operations by highlighting the main cultural dimensions at both national and organisational levels. We argue that current cultural dimensions are not sufficient in explaining the differences between nations. Thus we claim to add "Modernity-Traditionalism" dimension to be included while studying national culture. It extends to describe how the culture on its two levels, national and organisational, influences the use of IS. Depending on the national and organisational culture, the use of IT systems may not produce the desired organisational results. It is clearly noticed how cultural values shape the way in which information technology is used. Cultural values were embedded in the design and use of these technologies therefore culture should be acknowledged when introducing an IT system in order to resolve some problems associated with its use. As a result to attain the use of technology at the desired level cultural attributes should be considered in advance.

The above discussion focuses on addressing the different aspects of culture prevailing in business organisations. More specifically it illuminates the role of culture in IS implementation and diffusion to give an enriched understanding of the cultural settings that could help in clarifying the prospects of IS use. The overview of culture discussed separately here illustrates the importance of culture and the impact that each of Hofstede's dimensions has on IS implementation and use. In light of this the current use and future potential use of IS can be contextually understood with understanding and meaning.

Many writers i.e., Martinsons, (1994), Kanungo, (1998), and Ruppel \& Harrington (2001) have asserted that effective use of IS depends on the development of a corporate culture. Some recent studies also argue that an organization could achieve better use of IS through establishing supportive cultural attributes (Harper \& Utley, 2001, IritAlony, 2007, Kang \& Araújo, 2006). Thus, a firm should not only focus on developing technology but also establishing a corporate culture that concentrates on some corporate values such as competitiveness, 
productivity, flexibility, adhocracy, innovation, trust, and group cohesion.

\section{References}

Ahmed, P. K. (1998). Culture and climate for innovation. European Journal of Innovation Management, 1, 30-43. http://dx.doi.org/10.1108/14601069810199131

Ali, A., \& Wahabi, R. (1995). Managerial value systems in Morocco. International Studies of Management \& Organization, 25.

Ali, Pascoe, C., \& Warne, L. (2002). Interactions of organizational culture and collaboration in working and learning. Educational Technology \& Society, 5, 2002.

Barbu, Z. (1971). Society, culture, and personality: an introduction to social science. Schocken Books.

Brien, A. (1998). Professional ethics and the culture of trust. Journal of Business Ethics, 17, 391-409. http://dx.doi.org/10.1023/A:1005766631092

Cameron, K. S., \& Quinn, R. E. (2011). Diagnosing and changing organizational culture: Based on the competing values framework. Jossey-Bass.

Cameron, K., \& Quinn, R. (1999). Diagnosing and changing organizational culture: based on the competing values framework. Addison-Wesley.

Capon, C., \& Disbury, A. (2000). Understanding organisational context. Financial Times/Prentice Hall.

Chau, P. Y. K., Cole, M., Massey, A. P., Montoya-Weiss, M., \& O'keefe, R. M. (2002). Cultural differences in the online behavior of consumers. Commun. ACM, 45, 138-143. http://dx.doi.org/10.1145/570907.570911

Ciborra, C. (2000). From control to drift: the dynamics of corporate information infastructures. Oxford University Press.

Claver, E., Llopis, J., Gonzalez, M. R., \& Gascó, J. L. (2001). The performance of information systems through organizational culture. Information Technology \& People, 14, 247-260. http://dx.doi.org/10.1108/09593840110402149

Cooper, R. B. (1994). The inertial impact of culture on IT implementation. Information \& Management, 27 , 17-31. http://dx.doi.org/10.1016/0378-7206(94)90099-X

Daft, R., Lengel, R., Trevino, L., Texas, A., \& Research, U. S. O. O. N. (1986). The Relationship Among Message Equivocality, Media Selection, and Manager Performance: Implications for Information Support Systems. Texas A And M Univ College Station, Dept Of Management.

Davis, S. (1990). Managing corporate culture. Harper \& Row.

Elsayed-Ekjiouly, S. M., \& Buda, R. (1993). Organizational conflict: A comparative analysis of conflict styles across cultures. International Journal of Conflict Management, 7, 71-81. http://dx.doi.org/10.1108/eb022776

Evans, B., Jeffries, D., \& Reynolds, P. (1996). Training for Total Quality Management. Kogan Page.

Fink, D. (1998). Guidelines for the successful adoption of information technology in small and medium enterprises. International Journal of Information Management, 18, 243-253. http://dx.doi.org/10.1016/S0268-4012(98)00013-9

Giddens, A. (1984). The constitution of society: outline of the theory of structuration. University of California Press.

Gouldner, A. W. (1958). Cosmopolitans and locals: toward an analysis of latent social roles. II. Administrative Science Quarterly, 2, 444-480. http://dx.doi.org/10.2307/2390795

Hall, E. T. (1976). Beyond culture. Anchor Press.

Harper, G. R., \& Utley, D. R. (2001). Organizational culture and successful information technology implementation. Engineering Management Journal, 13, 11-15.

Hill, C. E., Loch, K. D., Straub, D. W., \& El-Sheshai, K. (1998). A qualitative assessment of Arab culture and information technology transfer. Journal of Global Information Management, 6, 29-38. http://dx.doi.org/10.4018/jgim.1998070103

Ho, T. H., Raman, K. S., \& Watson, R. T. (1989). Group decision support systems: the cultural factor. Proceedings of the tenth international conference on Information Systems. Boston, Massachusetts, United 
States: ACM.

Hofstede, G. (1980). Culture's consequences, international differences in work-related values. Sage Publications.

Hofstede, G. (1983). The cultural relativity of organizational practices and theories. Journal of International Business Studies, 14, 75-89. http://dx.doi.org/10.1057/palgrave.jibs.8490867

Hofstede, G. (1991). Cultures and organizations: software of the mind. McGraw-Hill.

Hofstede, G. (1998). Attitudes, values and organizational culture: Disentangling the concepts. Organization Studies, 19, 477. http://dx.doi.org/10.1177/017084069801900305

Hofstede, G. (2002). Dimensions do not exist: A reply to Brendan McSweeney. Human Relations, 55, 1355-1361. http://dx.doi.org/10.1177/0018726702055011921

Hofstede, G. (2005). Cultures and organizations: software of the mind. McGraw-Hill.

Inman, M., O'sullivan, N., \& Murton, A. (2010). Unlocking Human Resource Management. Oxford Univ Pr.

Iritalony, M. J. (2007). The cultural impact of information systems-through the eyes of Hofstede-a critical journey. Information and Beyond: Part I, 4, 407.

Johnson, G., Scholes, K., \& Whittington, R. (2008). Exploring corporate strategy: text \& cases. Financial Times Prentice Hall.

Kang, K., \& Araújo, J. (2006). Cultural and Requirement Aspects on International E-commerce sites. Las Vegas, Nevada, USA.

Kanungo, S. (1998). An empirical study of organizational culture and network-based computer use. Computers in Human Behavior, 14, 79-91. http://dx.doi.org/10.1016/S0747-5632(97)00033-2

Kaynak, E. (1986). International business in the Middle East. In Kaynak, E. (Ed.), International Business in the Middle East. Berlin: Walter de Gruyter.

Kim, D., Pan, Y., \& Park, H. S. (1998). High- Versus Low-Context Culture: A Comparison of Chinese, Korean and American Cultures. Psychology \& Marketing, 15, 507-521. http://dx.doi.org/10.1002/(SICI)1520-6793(199809)15:6<507::AID-MAR2>3.0.CO;2-A

Leidner, D. E., \& Kayworth, T. (2006). Review: A review of culture in information systems research: Toward a theory of information technology culture conflict. MIS Quarterly, 30, 357-399.

Leidner, D. E., Carlsson, S., Elam, J., \& Corrales, M. (1999). Mexican and Swedish Managers' Perceptions of the Impact of EIS on Organizational Intelligence, Decision Making, and Structure. Decision Sciences, 30, 632-658. http://dx.doi.org/10.1111/j.1540-5915.1999.tb00901.x

Marcus, A., \& Gould, E. W. (2000). Crosscurrents: cultural dimensions and global Web user-interface design. Interactions, 7, 32-46. http://dx.doi.org/10.1145/345190.345238

Martinsons, M. G. (1994). Benchmarking human resource information systems in Canada and Hong Kong. Information \& Management, 26, 305-316. http://dx.doi.org/10.1016/0378-7206(94)90028-0

Pun, K. F., Chin, K. S., \& Lau, H. (2000). A review of the Chinese cultural influences on Chinese enterprise management. International Journal of Management Reviews, 2, 325-338. http://dx.doi.org/10.1111/1468-2370.00045

Quaddus, M., \& Tung, L. L. (2002). Explaining cultural differences in decision conferencing. Communications of the ACM, 45, 93-98. http://dx.doi.org/10.1145/545151.545157

Quinn, R. (1988). Beyond Rational Management: Mastering the Paradoxes and Competing Demands of High Performance. Natl Book Network.

Rhinesmith, S. (1970). Cultural-organizational analysis: the interrelationship of value orientations and managerial behavior. McBer.

Robbins, S. P. (1990). Organization theory: structure, design, and applications. Prentice Hall.

Robey, D., \& Rodriguez-Diaz, A. (1989). The organizational and cultural context of systems implementation: Case experience from Latin America. Information \& Management, 17, 229-239. http://dx.doi.org/10.1016/0378-7206(89)90046-3

Rose, G. M., Evaristo, R., \& Straub, D. (2003). Culture and consumer responses to Web download time: A four-continent study of mono and polychronism. Engineering Management, IEEE Transactions on, 50, 
31-44. http://dx.doi.org/10.1109/TEM.2002.808262

Ruppel, C. P., \& Harrington, S. J. (2001). Sharing knowledge through intranets: A study of organizational culture and intranet implementation. Professional Communication, IEEE Transactions on, 44, 37-52. http://dx.doi.org/10.1109/47.911131

Sabherwal, R., \& Chan, Y. E. (2001). Alignment between business and IS strategies: A study of prospectors, analyzers, and defenders. Information Systems Research, 12, 11. http://dx.doi.org/10.1287/isre.12.1.11.9714

Schein, E. H. (2010). Organizational Culture and Leadership. John Wiley \& Sons.

Steensma, H. K., Marino, L., Weaver, K. M., \& Dickson, P. H. (2000). The influence of national culture on the formation of technology alliances by entrepreneurial firms. Academy of Management Journal, 43, 951-973. http://dx.doi.org/10.2307/1556421

Straub, D., Keil, M., \& Brenner, W. (1997). Testing the technology acceptance model across cultures: A three country study. Information \& Management, 33, 1-11. http://dx.doi.org/10.1016/S0378-7206(97)00026-8

Swierczek, F. W. (1994). Culture and conflict in joint ventures in Asia. International Journal of Project Management, 12, 39-47. http://dx.doi.org/10.1016/0263-7863(94)90008-6

Tolsby, J. (1998). Effects of organizational culture on a large scale IT introduction effort: a case study of the Norwegian army's EDBLF project. European Journal of Information Systems, 7, 108-114. http://dx.doi.org/10.1057/palgrave.ejis.3000295

Twati, J. M., \& Gammack, J. G. (2006). The impact of organisational culture innovation on the adoption of IS/IT: the case of Libya. Journal of Enterprise Information Management, 19, 175-191. http://dx.doi.org/10.1108/17410390610645076

Wallach, E. J. (1983). Individuals and organisations: the cultural match. Training \& Development Journal, 37, $28-35$.

Ward, J., \& Peppard, J. (2002). Strategic planning for information systems. J. Wiley.

\section{Copyrights}

Copyright for this article is retained by the author(s), with first publication rights granted to the journal.

This is an open-access article distributed under the terms and conditions of the Creative Commons Attribution license (http://creativecommons.org/licenses/by/3.0/). 